
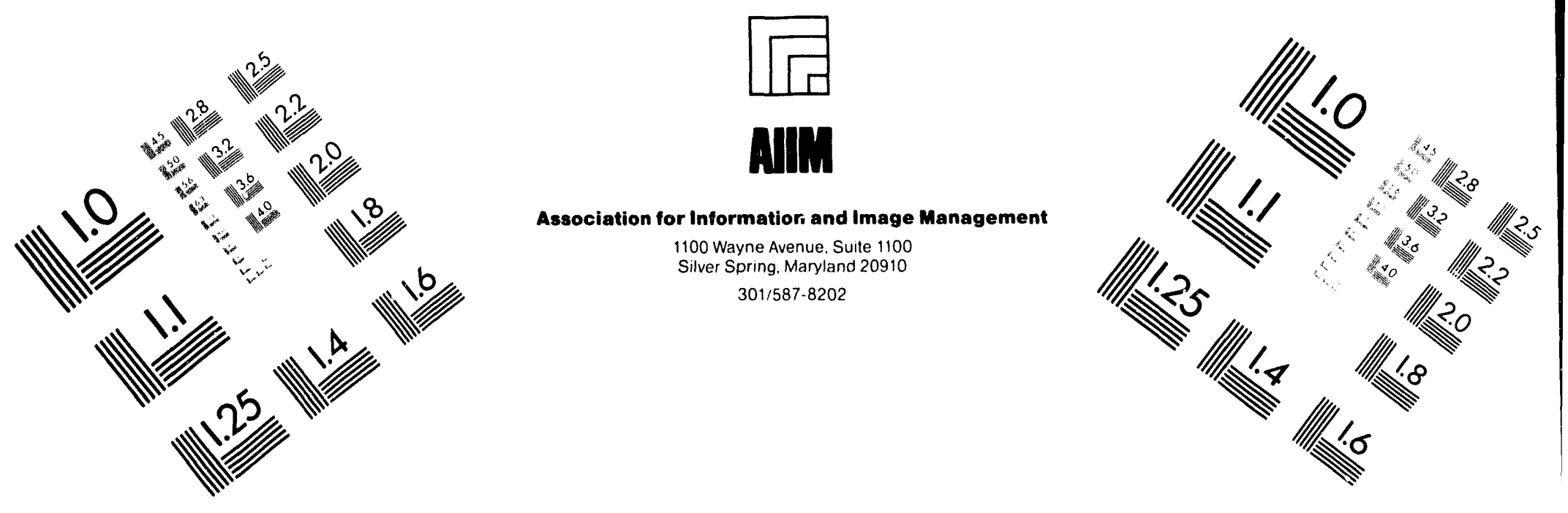

\title{
Centimeter
}

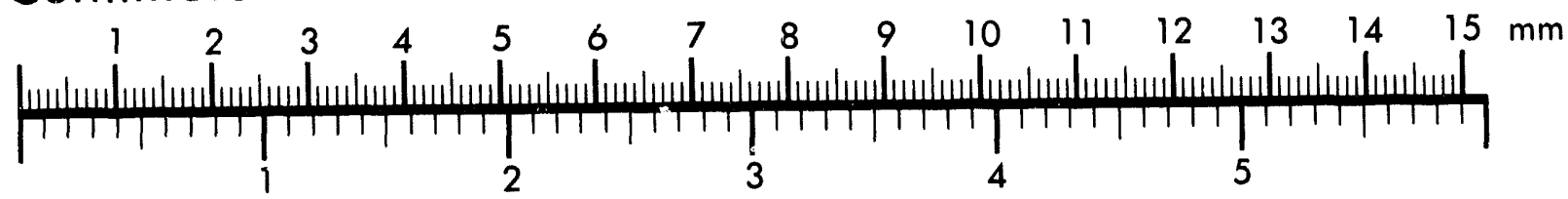
Inches
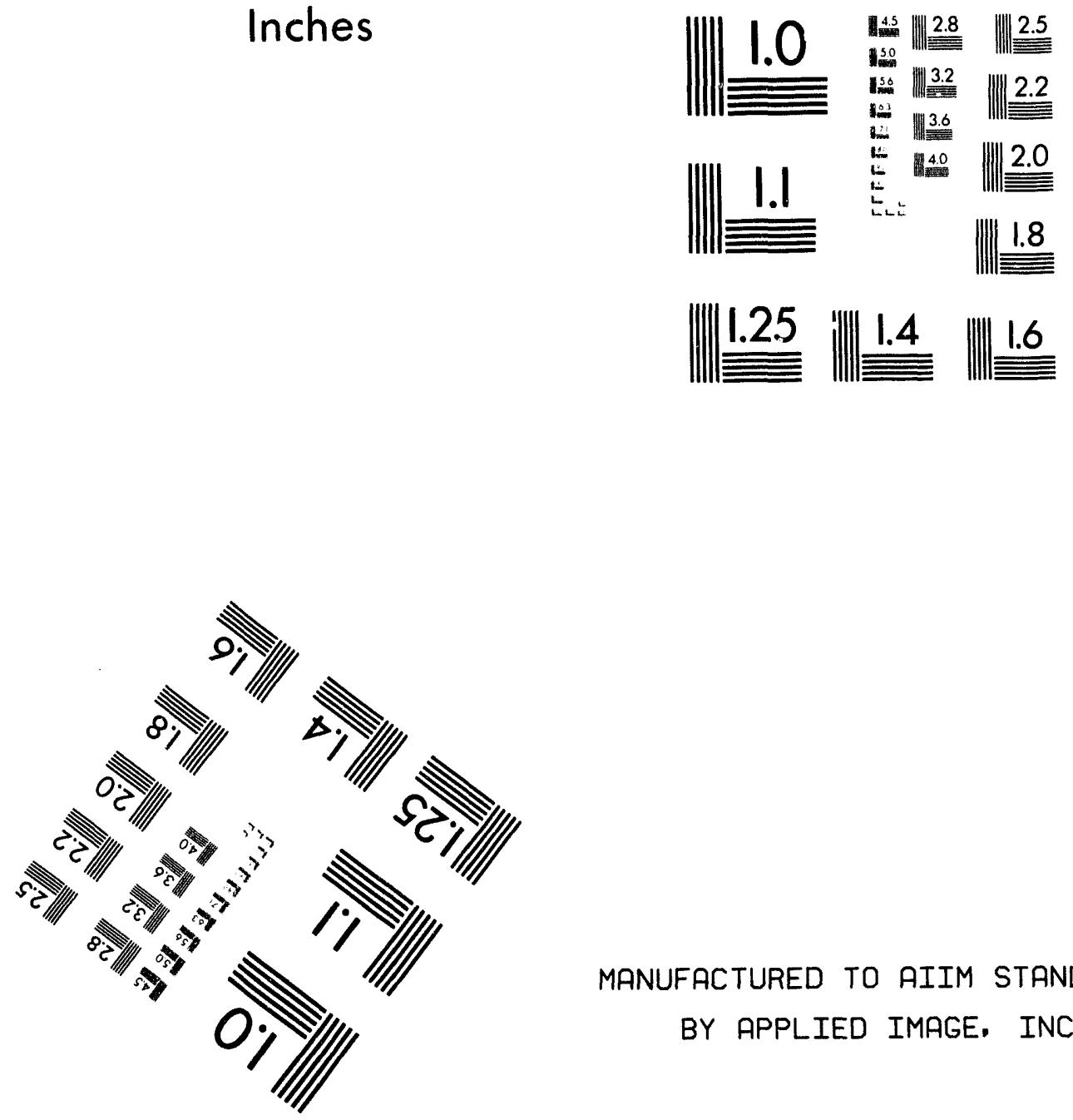

MANUFACTURED TO AIIM STANDARDS BY APPLIED IMAGE. INC.

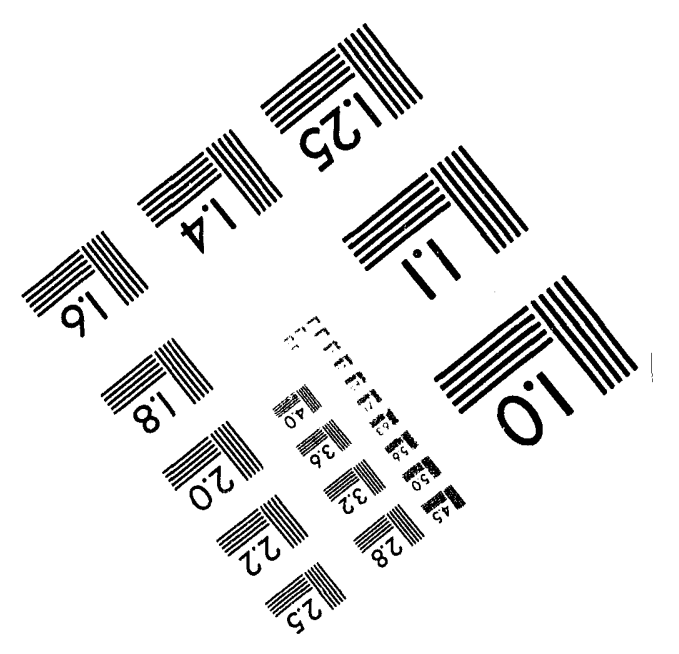



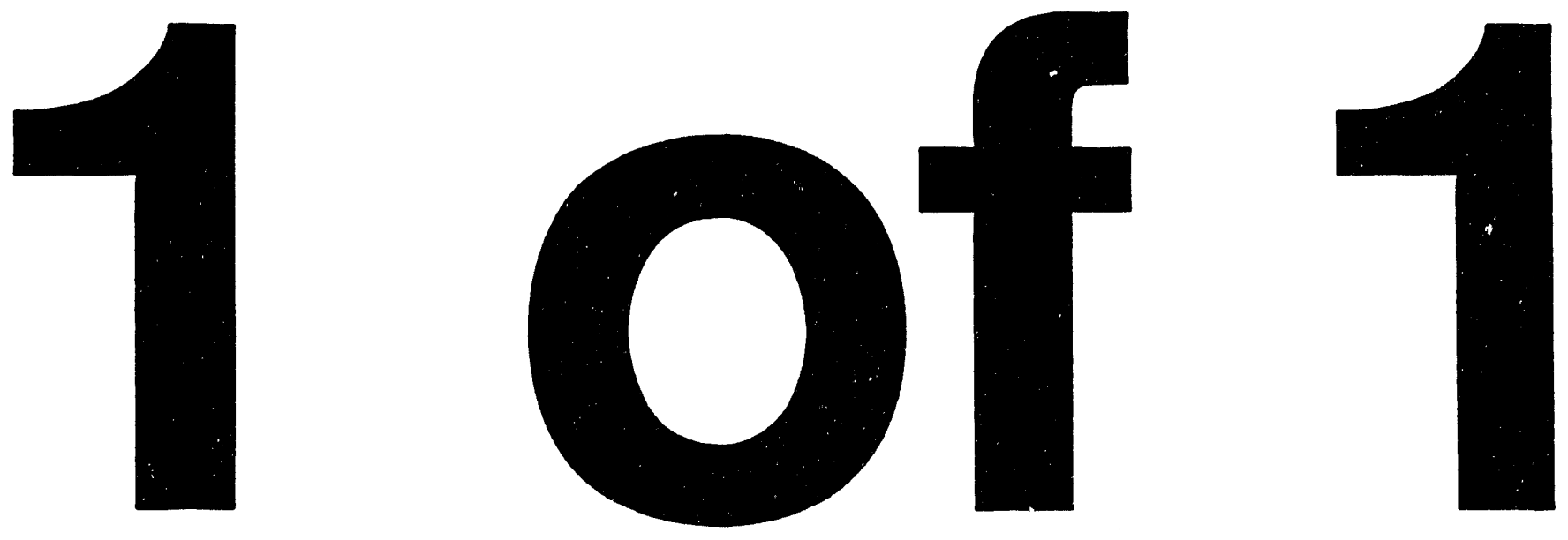
FRICTION WELDING METHOD OF HOT ISOSTATIC PRESS CAN CLOSURE FOR THE ICPP CALCINE IMMOBILZATION PROGRAM

S. M. Berny (WINCO)

T. R. Reed (EG\&G)

R. C. Swainston (EG\&G)

September 1993

(). Westinghouse Idaho Nuclear Company. Inc.

PREPARED FOR THE

DEPARTMENT OF ENERGY IDAHO OPERATIONS OFFICE UNDER CONTRACT DE-ACC7-841D12435 


\section{FRICTION WELDING METHOD OF HOT ISOSTATIC PRESS CAN CLOSURE FOR CALCINE IMMOBILIZATION PROGRAM}

\section{INTRODUCTION}

An investigation of various closure techniques was performed in an effort to meet requirements for closure of evacuated waste cans to be used at Westinghouse Idaho Nuclear Company's Idaho Chemical Processing Plant.

Although other sealing techniques are available. welding was considered to be the best for sealing the cans. For various reasons, techniques other than welding are not suitable for cans that are subject to the Hot Isostatic Press (HIP) process. For example, elastomeric seals, solders, and brazing would not withstand the temperature associated (approximately 1000 degrees centigrade) with the HIP process. Mechanical joining techniques such as threading. crimping, and swaging could result in the joint opening as the can wall is deformed during HIP process. Unlike the above joint methods, welding results in physical joining of the lid or plug to the can itself, thus the wall would have to be ruptured before leakage would occur.

The following welding techniques were investigated for application to the can closure, but were eliminated from consideration for various reasons. A short explanation of the reasons from elimination are included with each welding method. Where applicable, the American Welding Society (AWS) acronym is included with each welding type.

Arc Welding This general category includes welding operations where an electric arc is used in the process. These include such processes as Shielded Metal Arc Welding (SMAW). Gas Tungsten Arc Welding (GTAW), Gas Metal Arc Welding (GMAW). Flux Cored Arc Welding (FCAW), Submerged ArC Welding (SAW), Electrogas Welding (EGT), Plasma ArC Welding (PAW), Carbon Arc Welding (CAW). Atomic Hydrogen Welding (AHW), and Bare Metal Arc Welding (BMAW). These methods are unsuitable because an arc cannot be maintained without a gas present to ionize. Since the can volume is to be maintained at 0.1 torr during the closure, it is desirable to perform the weld under vacuum conditions. A secondary seal system could be employed during welding. but is judged to be an unnecessary complication. 
Electroslag Welding (ESW) This method of welding is suitable for materials of at least 3/4-inch thickness, and joints that are oriented vertically. These limitations are not consistent with proposed waste can configurations.

exyfuel Gas Welding (OGW) This method is unsuitable because combustion products from the burning gases would interfere with the required vacuum level.

Pressure Gas Welding (PGW) Since this process also uses oxyfuel as the heat source, it is unsuitable for the same reasons as Oxyfuel Gas Welding (listed above).

Eorge Welding (FOW) Blows to the heated work pieces are used in this method. Accomplishing this mechanical process in a vacuum environment is not considered to be practical.

Cold Welding (CW) This technique is best suited to small cross-section work pieces and is limited to materials such as soft temper copper or aluminum, as well as gold. platinum and palladium. This limitations are not consistent with the proposed waste can configuration.

Explesion welding This welding method was eliminated from consideration due to the safety implications of explosions inside of a hot cell.

Ultrasonic Welding (USW) This method is limited to thin material and lap joints. This is not consistent with the current requirements of the prototype waste can.

Diffusion welding (DFW) This method was not considered due to reported inadequate nondestructive inspection techniques. Another limitation is the stringent cleanliness requirements on the faying surfaces. Since the calcined waste is likely to collect on the faying surfaces as the can is filled. an additional cleaning operation would be required.

The following welding processes were judged to be suitable for can closure. All of these mechods have thelr advantages and disadvantages. the most notable of which are listed.

Besistance Seam Welding (RSEW) This is a viable method for performing the weld. It has the advantage of having a low dependency on operator skill and being very repeatable. However, the machine necessary to perform the weld would be large, mechanically complex, and expensive. 
Typical current for joints of 0.1 inch material is 20.000 Amps. The electrode/roller assembly would have to be located in the vacuum chamber inside the hot cell. making it very difficult to maintain.

Electron Beam Welding (EBW) This process is well suited to a vacuum. and. in fact. works best in a vacuum. The electron gun in this system operates at $10^{-4}$ torr, and ideally, welds should be made at this vacuum level. Welding can occur at less severe vacuum levels by shooting the electrons out of the electron gun vacuum chamber through a small beam hole. Thus the gun chamber vacuum system must be sized to keep up with the backstreaming (leak) through the beam hole. This differential pressure will lead to contamination migration from the welding chamber $\left(10^{-1}\right.$ tor $\left.r\right)$ into the electron gun chamber $\left(10^{-4}\right.$ torr $)$. The can could be welded at $10^{-4}$ torr. but this would mean that the entire contents of the waste can would have to be pumped down to this high vacuum level. This would mean longer pumpdown times and additional expensive and maintenance intensive high vacuum equipment. Even in this case, the electron gun would become contaminated. Periodic service to the electron gun is expected. which means routine personnel access to the hot cell. There is a reported move away from EBW in the industry due the high maintenance cost and down time. Therefore, used electron beam machines are relatively easy to obtain. One of the major advantages of EBW is the high weld speeds. However, this is not a major concern in our application. Another limitation to EBW is that due to the tightly focused beam, the weld joint must be maintained to close tolerances. In general, electron beam welding machines are expensive. intricate. difficult to maintain. and dependent on operator skill.

Laser Welding (LW) This process is also well-suited to a vacuum environment. LBW and EBW are similar in many respects. Both machines are complex, difficult to maintain, and dependent on operator skill. For a given power. LBW is more expensive than EBW. However. LBW has some distinct advantages over EBW in the INEL application. The majority of the machine can be located outside the hot cell wall and the beam transferred via windows to the inside of the hot cell and the inside of the vacuum chamber. An advantage to EBW and LBW is that weld repair may be possible at the same station. A potential problem area for the LBW is identifying adequate window material that will withstand the laser power and not darken due to radiation effects.

Upset Welding (UW) This method is similar to friction welding (see below) in that heat is produced at the faying surfaces and then forced 
together. In upset welding, heat is produced by the resistance to electrical current while in friction welding, heat is produced by the friction of the rubbing surfaces. The UW process is mechanically simple and not subject to operator error. The majority of items that need maintenance can be located outside of the hot cell wall. The major disadvantage of this technique is the size and expense of the electrical components necessary to produce sufficient currents to properly weld larger cross sections. Another major disadvantage to the UW process is its weld repair impracticality. Should the weld prove to be bad. performing a new weld is the only feasible option. An option in some can applications is to incorporate a secondary weld joint entirely separate from the first weld. In the case of the INEL waste can. however, this poses a problem. If the weld is found to be defective, it is also likely that there is also no longer a vacuum in the can. Since the can is now essentialiy closed. pumping the contents down to $10^{-1}$ torr could be very difficult. Thus, even if the weld could easily be repaired. a hole may need to be opened up to allow the can to be pumped down. Therefore, this difficulty in weld repair may not be a serious disadvantage, since all weld repairs, regardless of weld type, may require the reopening of the can.

Eriction Welding (FRW) This is the recommended welding technique. Although the equipment to perform friction welds is large and heavy, it is mechanically simple, robust, and easy to maintain. The only major components are a rotating inertial weight, electric motor. clutch, and hydraulic cylinder. All of these components can be mounted on the clean side of the hot cell wall for ready maintenance. This concept is not dependent on operator skill. Once the machine is set up. all the operator has to do is sequentially push buttons. The friction weld works well in a vacuum and is tolerant of joint imperfections and joint cleanliness. Joints made in this manner are stronger than the parent metal and are vacuum tight. One of the disadvantages to friction welding is the weld parameters have to be determined for each application and the machine appropriately designed. However. once the weld parameters (flywheel inertia. flywheel speed, forging force, and axial displacement) are established and set on the machine, weld reject rate is much lower than other methods. Minor variations in the weld parameters typically do not have a detrimental effect on weld quality or sealing capability. Axial forces required to make a friction weld are typically high $(20,000$ psi contact pressure) which can make the machine very large. To reduce this effect. we are proposing the use of a tapered plug which will have high contact forces without the need for 
high axial forces. This will reduce the need for large equipment and heavy wall thicknesses on the cans. Friction welding will require a portion of the can to be relatively thick. On the order of 0.25 inches. This friction weld portion of the can can also be used as the attachment point for the required overhead lifting fixture. Like UW. weld repair of FRW is impractical. However. unlike UW. it may be possible to attach a cutting head to the existing ratating shaft and cut out the bad weld. A new plug could then be inserted. Thus the friction weld station may also double as the weld repair station.

As an independent check on these conclusions, a report generated by Lawrence Livermore National Laboratory (LLNL). "Closure Development for High-Level Nuclear Waste Containers for the Tuff Repository," UCRL-15964, was reviewed. LLNL's requirements for a closure system have many of the same elements as WINCO's. In particular, the LLNL process had to produce a reliable leak-tight weld in a hot cell environment. This closure will have to be NDE inspected to verify integrity before leaving the hot cell. An additional INEL requirement which LLNL did not have is the necessity of maintaining a vacuum in the interior of the can during the welding process.

In the LLNL report. FRW was the top-rated process followed by GTAW. PAW. LBW. and EBW. As noted above. GTAW and PAW cannot be performed in a vacuum. The only significant drawbacks noted to the FRW process was the size and expense of the equipment and the difficulty of weld repair. In defense of FRW. this equipment is only expensive in relation to GTAW and PAW. LBW and EBW machines can easily be more expensive than FRW. The LLNL report did not address UW because at the time of publication. there were no commercially available machines which could produce the currents necessary to weld the desired crosssections.

\section{TEST DESIGN AND OBJECTIVES}

Although friction welding is a mature technology and is generally well understood. two additional constraints were placed on the HIP Evacuated Can Closure (HECC) testing to prove application to the HIP cans. First, this testing was designed to prove that a tapered plug could be welded into a hole in a flat plate. Traditional applications of friction welding requires shafts or tubes to be forced together with the welding faces perpendicular to the axis of symmetry. In some published plugging applications, the welding face is at 30 or 45 degrees to the axis. However. in the HECC process, it was desired to use a more steeply tapered plug to achieve the high normal forces necessary to accomplish a friction weld without high axial forces. A 15 - 
degree taper was used to reduce the normal force requirement by a factor of four. thus reducing the thickness requirements of the HIP can lid.

A second area of investigation was to prove that the friction welding could be done in a vacuum environment. A two-inch diameter plug size was chosen based on initial information from WINCO's Applied Technology - Process Development Organization. Further evaluations at WINCO will optimize the HIP can fill hole diameter. Using this initial plug size, welding parameters such as energy requirements, normal force requirements, and adequate joint geometries could be determined. An appropriate prototype machine could then be designed accordingly. From the literature on friction welding. it was predicted that $43.000 \mathrm{ft}-1 \mathrm{~b}$ of energy would be required to produce a 0.25 -inch thick weld on a 2 -inch diameter. Also, to achieve the desired 20,000 psi joint pressure, an axial force of 8400 lbs would be necessary. To reduce costs. initial testing was done at atmospheric conditions and centered around proving the concept of using a tapered plug. Once experience was gained in this area, testing proceeded into welding under vacuum conditions.

\section{IEST SET-UP}

A large lathe at the Prototype Engineering Laboratory (Central Facilities Area. Building $(F-688)$ was used in performing the friction weld testing. Figure 1 in the attachments shows the primary pieces of equipment in the test arrangement. The lathe was used as a means to turn the flywheel and support the axial forces necessary to perform the weld. The flywheel sections were 18 inch diameter pieces of 3 inch thick steel plate, and were turned by the lathe chuck to achieve the desired speed. When at the maximum speed of the lathe (1066 rpm) this flywheel assembly provided a total energy storage of 48.000 ft-lbs. A remotely actuated pneumatic clutch was used between the flywheels and the lathe chuck to allow the flywheel to spin down at its own speed without being driven or slowed down by the lathe drive mechanism. The lathe steady rest was modified to accept a bearing which supported the end of the rotating shaft and flywheel assembly. An encoder disk was attached to the flywheel shaft to provide rotational speed indication. Two different specimen arrangements were used, one for atmospheric specimen testing and one for vacuum specimen testing. Although not part of the original design, a slip clutch was incorporated into the apparatus to prevent damage to equipment by limiting the peak torque. A torque transducer was included to measure the torque produced during the weld process. The lathe tailstock spindle was removed and replaced by a specially designed hydraulic cylinder which forced the simulated can lid into the rotating plug. In a final machine configuration the can could be held stationary and the rotating plug forced 
into the can lid. A torque arm was attached to the hydraulic cylinder ram to prevent the ram from turning during the welding process. A hydraulic system shown in Figure 2 was fabricated to supply pressure to the tailstock ram. A nitrogen bottle was used to pressurize a hydraulic accumulator which in turn pressurized the double acting tailstock cylinder. To initiate the welding process. a solenoid valve was opened to allow fluid to flow into the hydraulic fluid reservoir. To place the cylinder back into a starting position. a hand hydraulic pump was used to pump hydraulic fluid from the reservoir back into the tailstock cylinder. Instrumentation was attached to this setup to provide torque, speed, cylinder pressure, and vacuum level. Two different specimen arrangements were used. The atmospheric specimen arrangement shown in figure 3 was used to minimize the cost associated with preparing specimens. Figure 4 illustrates the vacuum specimen arrangement which uses an 0 -ring sealed vacuum head to maintain a vacuum in the weld area. This vacuum arrangement also utilizes a flange on the simulated can lid which acts as a sealing surface as well as a future lifting point for remote handling operations.

\section{IEST PROCEDURE}

1. Attach test specimens

2. Pressurize hydraulic system

3. Pump vacuum head to 50 millitorr (vacuum test only)

4. Engage pneumatic clutch

5. Start lathe and bring flywheel up to desired speed

6. Close vacuum head valve and detach vacuum pump (vacuum test only)

7. Disengage pneumatic clutch

8. Open solenoid valve to actuate tailstock ram

9. Close solenoid valve at completion of weld

10. Return ram to starting position

11. Remove test specimens

\section{IEST DATA}


Data from the tests are listed in tabular form on Figures 5 and 6 . Listed below are explanations of the different headings.

Iest Number This is the chronological order of the tests. The atmospheric tests have a number only, while the vacuum tests have a VAC suffix to the number.

Joint Geometry Figure 7 illustrates the different geometries used along with their respective letter designation.

Welding Torque This is the average torque of the plug acting against the simulated can lid. See figure 8.

Peak Torque This is the maximum torque recorded after welding has occurred. See Figure 8.

Welding Force This is the force applied by the tailstock cylinder which forces the plug and the lid together.

Joint Surface Pressure This is the pressure at the faying surfaces of the weld joint and is influenced by the angle of the plug i.e. the smaller the angle the larger the surface pressure.

Weld Time This is the time between when the plug first makes contact with the lid and the peak torque occurs. See figure 8 .

Weld Area This is the weld area between the plug and the simulated can lid.

Unit Weld Energy This the calculated weld energy per unit of weld area.

Leak Rate This is the helium leak rate of the joint after welding. In those entries noted with an asterisk. this was the minimum value attainable by the leak detector due to an insufficient supply of liquid nitrogen for the vacuum pump cold trap. The actual leak rate of the weld joint will be less than this number.

\section{IEST OBSERVATIONS. ATMOSPHERIC}

1. Peak torques were much higher than expected, while welding torques were close to predicted amounts. The predicted peak torque from published data was approximately 1.5 times the weld torque. The measured peak 
torque was about 5 times the weld torque. These torque peaks caused deformation in the plug drive hex as well as the shaft end. and eventually led to failure of a torque transducer. The plug drive hex and shaft end deformation was solved by increasing the depth of hex engagement. However. concerns for potential damage to other equipment and possible detrimental effects to the weld joint after welding led to the decision to install a slip clutcil to limit the peak torque to 2.5 times the weld torque. Since this clutch was not a part of the original design. it was difficult to add this feature to the desirable location on the end of the flywheel shaft. Thus the slip clutch was added to the lid portion of the weld specimen which necessitated the removal of the vacuum pump prior to welding. All atmospheric tests were done without the benefit of a slip clutch, while all the vacuum tests were done with the slip clutch.

2. Joint geometry plays a big factor in the quality of the weld. The initial try of joint geometry ' $A$ ' matched the angle of the plug to the angle of the hole in the lid. On a section examination of the weld there appeared to be a problem with ejection of the weld flash out of the weld zone which led to insufficient bonding. In an effort to allow more open area to transport the weld flash away from the weld zone a straight hole through the lid was tried as shown in geometry ' $C$ '. This appeared to be an improvement but still showed a problem on the bottom side of the weld. This led to the test of joint geometry ' $D$ ' which allowed even more room for ejection of the weld flash. Joint geometry ' $E$ ' was an attempt to further ease the fiash ejection and indeed produced the best looking weld, though not measurably better than joint geometry ' $D$ '.

3. Required unit weld energies were higher than the predicted amount. Those geometries which resulted in a smaller weld area produced the best welds. When changing weld geometry, it is hard to separate the effects of increased unit weld energy from weld flash ejection ease. It would be desirable to try joints at a higher weld energy. However all testing was conducted at the maximum weld energy attainable for our test setup.

\section{IEST OBSERVATIONS, VACUUM}

1. Weld time is reduced in a vacuum. The first test in a vacuum failed to seal when using the same weld parameters and joint geometries which were successful in an atmospheric test. It was believed that this shorter weld time did not allow the tailstock hydraulic cylinder to react fast 
enough to produce full welding force throughout the weld process. To minimize this possibility, the size of the hydraulic lines to this cylinder were increased to allow faster ram speeds. All subsequent tests produced adequate welds.

2. Welds performed in a vacuum have an inferior appearance to the atmospheric tests. The vacuum tests met the objectives of sealing and producing a high strength joint but the flow of flash from the joint does not appear to be as good as the atmospheric tests. The shorter weld time associated with the vacuum welding may allow insufficient heat soak into the joint. In many commercial friction welding applications. an initial reduced welding force is used. This would tend to increase the weld time and allow more time for heat soak.

3. The vacuum in the test chamber decreased from 50 millitor to approximately 200 millitorr as the welding began. This is believed to be the result of air molecules being dragged into the chamber as the shaft is linearly translated through the seal.

4. On test number $3 V A C$ a leading chamfer of $1 / 16$ inch was mistakenly placed on the leading edge of the lid hole. This appeared to have a detrimental effect on the weld due to decreased flash ejection from the weld. The sharp leading edge used on subsequent test produced better flash ejection.

\section{RESULTS}

1. Friction weiding can produce high quality seals under vacuum conditions. Figure 9 shows a $3 x$ and a $100 x$ photo of a typical weld joint cross section. The last four vacuum tests produced seals with the helium leaks of no more than $1 \times 10^{.9} \mathrm{~atm}-\mathrm{cc} / \mathrm{sec}$. If a one cubic foot can was used. this leak rate would allow the can to leak up from 0.1 torr to 1.0 torr in approximately 1000 years.

2. Friction welding under vacuum conditions can produce a high strength weld. Two tensile strength specimens were tested which indicated weld strengths of approximately 77.000 psi. essentially the strength of the parent material. Figure 10 shows a picture of the fracture faces. The specimens broke at the weld. which was the smallest cross sectional area.

3. Friction welding under vacuum conditions produces minimal hardness 
increases in the weld. Figure 11 illustrates hardness increases across the weld and a $50 x$ reference photo of the hardness test area.

\section{SUGGESTED FURTHER TESTING AREAS}

1. Weld tests should be accomplished using a two stage weld process. In these tests the weld force would be reduced at the beginning of the weld process to lengthen the weld time and improve the heat soak. Near the end of the weld process the weld force could then be increased to achieve the high recommended forging pressures.

2. :hen the optimum HIP can fill hole size has been determined, further joint geometries should be perused which vary the geometry of the lid as vell as the plug.

3. Increased unit weld energy studies should be investigated to see if joints that are the full thickness of the lid ( 0.25 inches) can be made. These higher unit weld energies may also lead to better flash ejection.

4. The vacuum head shaft seals should be configured with lip seals rather than 0 -ring seals to see if the vacuum leak during shaft translation can be reduced.

5. Once HIP can fill hole size and can vacuum levels have been optimized by WINCD, and weld joint geometry and weld parameters are finalized in the above suggested testing. multiple weld samples should be tried to verify weld consistency.

\section{CONCLUSIONS}

Friction welding of HIP evacuated cans shows great promise. Although the process is not perfected. the limited samples tested produced high-strength. low-leakage seals which appear to meet current HECC requirements. Further development would likely reduce joint leakage to the instrumentation detectable limits and produce more consistent results. Enough information now exists to design an effective, dedicated HECC friction welding machine. A new machine should provide the ability to vary weld parameters over a range of approximately $-50 \%$ to $+100 \%$ of the current weld parameters. 


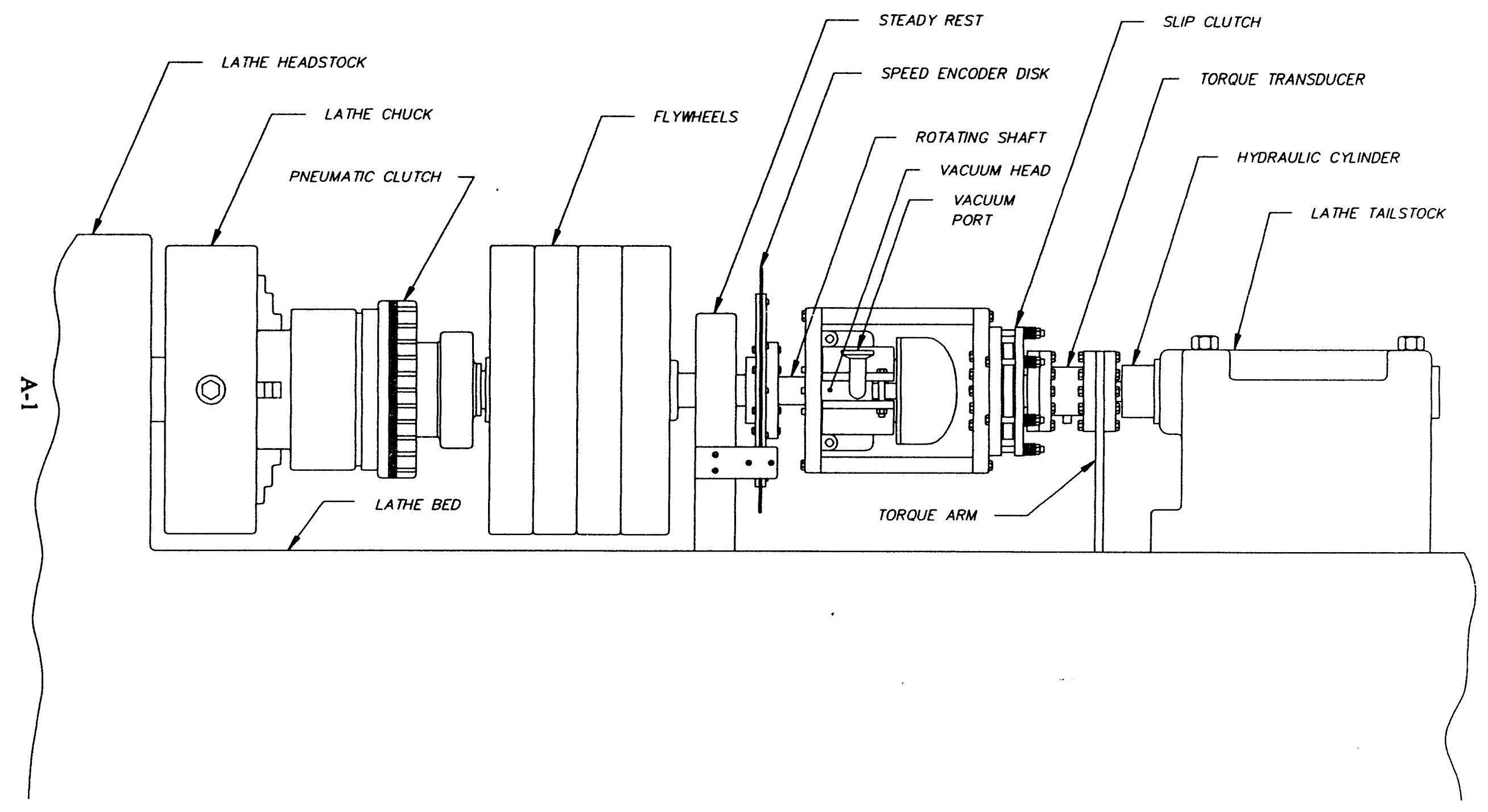

FIGURE 1

HECC FRICTION WELDING

LATHE MOUNTED EQUIPMENT 


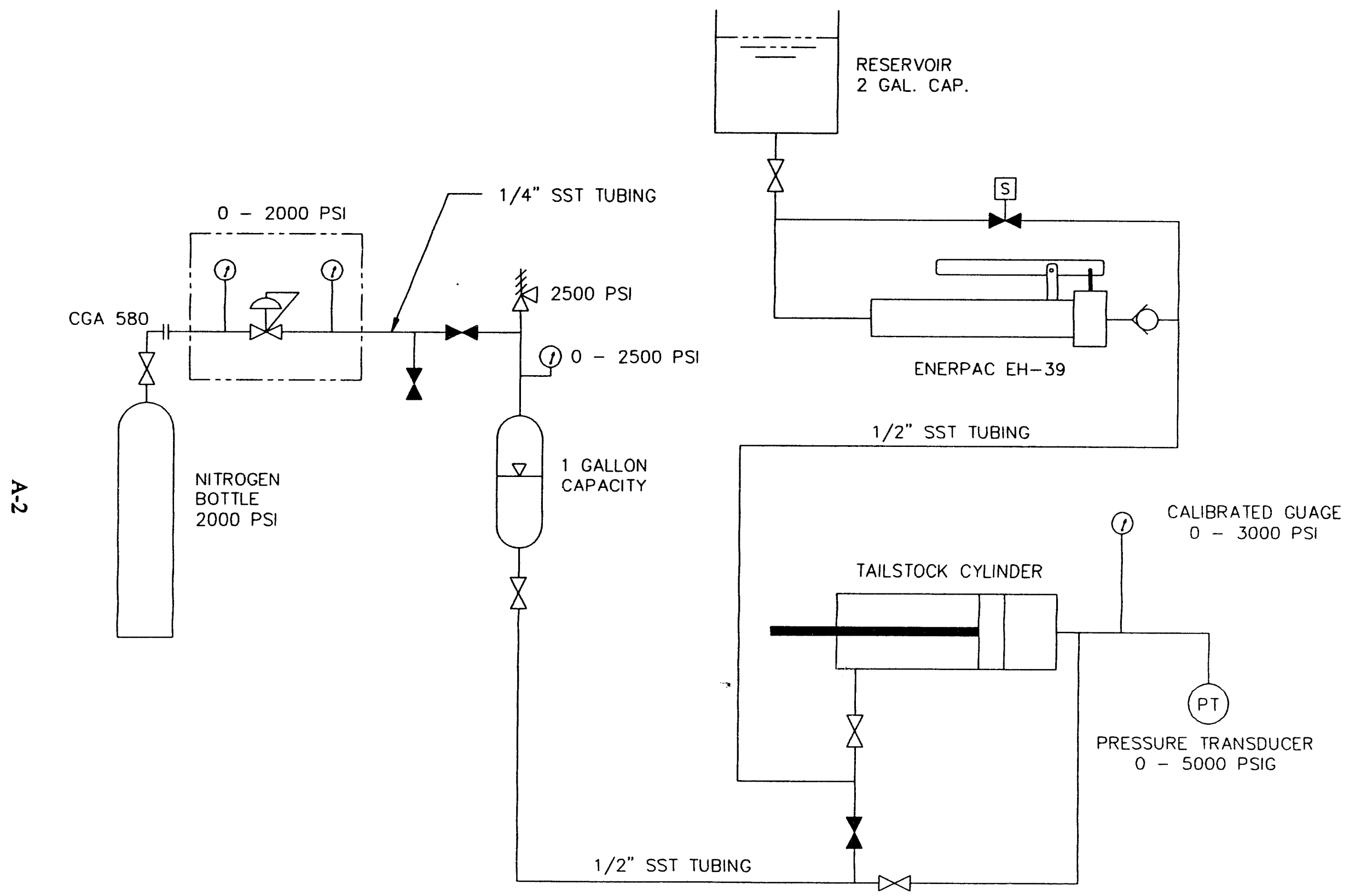

FIGURE 2

HECC FRICTION WELDING

WELD FORCE PRESSURIZATION EQUIPMENT 


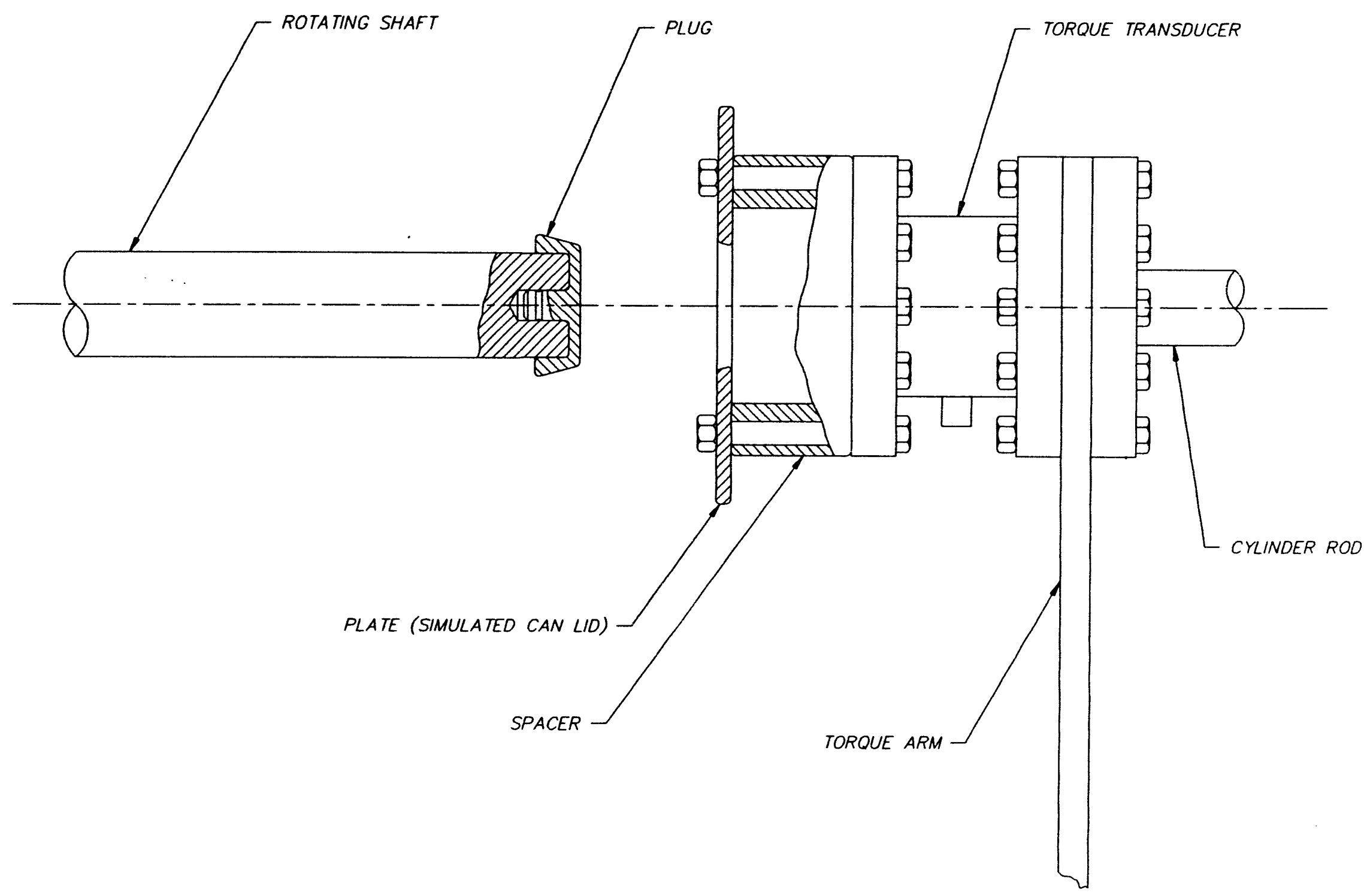

FIGURE 3

HECC FRICTION WELDING

ATMOSPHERIC SPECIMEN ARRANGEMENT. 

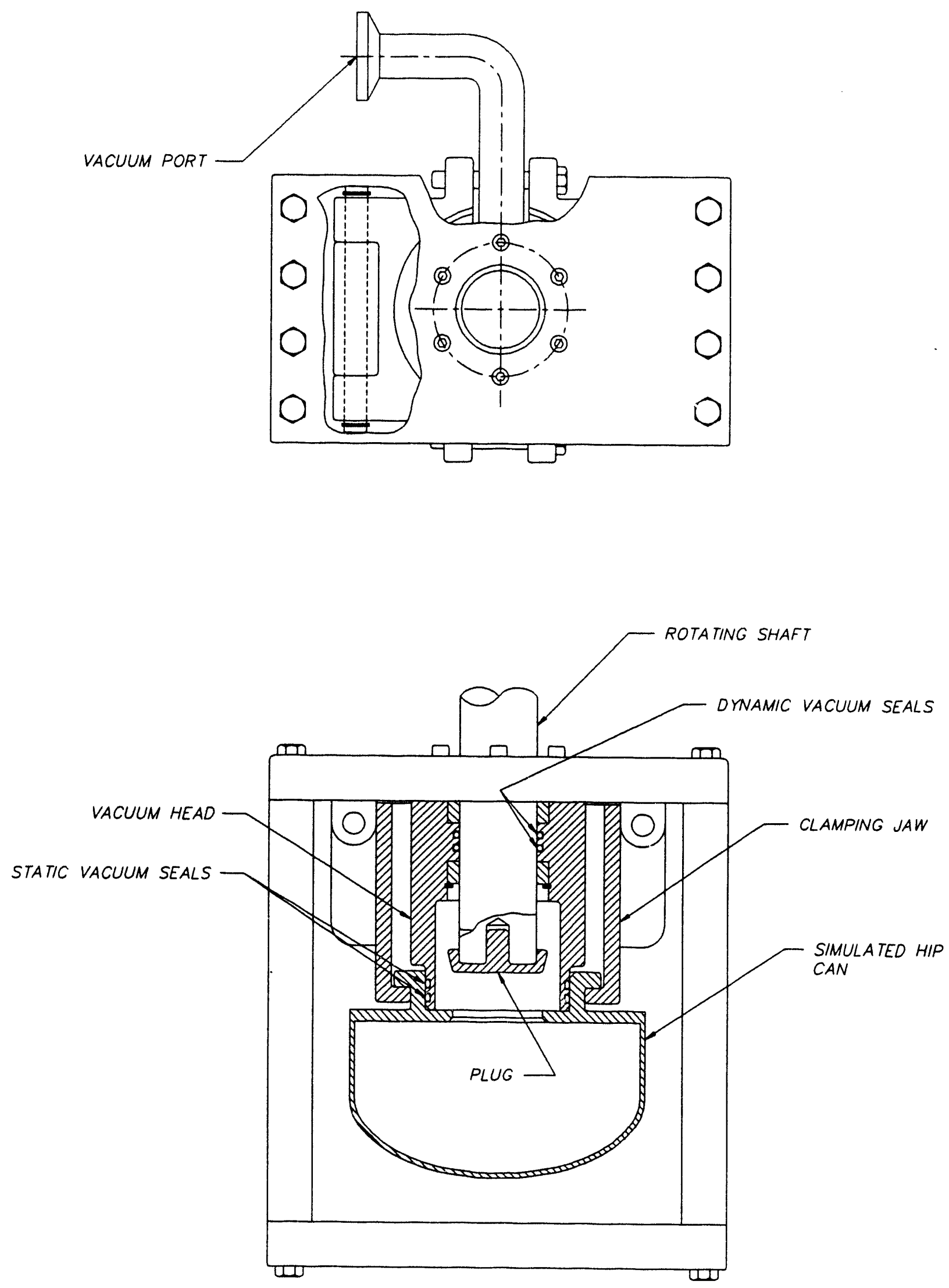

FIGURE 4

HECC FRICTION WELDING

VACUUM SPECIMEN ARRANGEMENT 
ATMOSPHERIC TEST DATA

\begin{tabular}{|c|c|c|c|c|c|c|c|c|c|c|}
\hline $\begin{array}{c}\text { TEST } \\
\text { NUMBER }\end{array}$ & $\begin{array}{c}\text { JOINT } \\
\text { GEOMETRY }\end{array}$ & $\begin{array}{l}\text { WELDING } \\
\text { TORQUE } \\
\text { (ft-lbs) }\end{array}$ & $\begin{array}{c}\text { PEAK } \\
\text { TORQUE } \\
\text { (ft-lbs) } \\
\end{array}$ & $\begin{array}{l}\text { WELDING } \\
\text { FORCE } \\
\text { ( l bs) } \\
\end{array}$ & $\begin{array}{l}\text { JOINT } \\
\text { SURFACE } \\
\text { PRESURE } \\
\text { (psi) } \\
\end{array}$ & $\begin{array}{l}\text { WELD } \\
\text { TIME } \\
(\mathrm{sec}) \\
\end{array}$ & $\begin{array}{l}\text { WELD } \\
\text { AREA } \\
\left(\text { in }^{2}\right) \\
\end{array}$ & $\begin{array}{r}\text { UNIT WELD } \\
\text { ENERGY } \\
\left(\mathrm{ft}-\mathrm{lbs} / \mathrm{in}^{2}\right) \\
\end{array}$ & $\begin{array}{l}\text { LEAK RATE } \\
(\mathrm{atm}-\mathrm{cc} / \mathrm{sec})\end{array}$ & COMMENTS \\
\hline 1 & A & 220 & 1.500 & 5.000 & 11,925 & 2.50 & 1.62 & 29.630 & ${ }^{*}<1 \times 10^{-8}$ & $\begin{array}{l}\text { PEAK TORQUE MUCH HIGHER THAN } \\
\text { EXPECTED. THIS WAS POSTULATED } \\
\text { TO BE A RESULT OF THE NARRON } \\
\text { TAPER ANGLE. INSUFFICIENT } \\
\text { BONDING AT EDGES OF WELD. }\end{array}$ \\
\hline 2 & B & - & - & 10.000 & 8.470 & - & 1.67 & 28,740 & $\begin{array}{l}\text { GROSS } \\
\text { LEAK }\end{array}$ & $\begin{array}{l}\text { THE } 45^{\circ} \text { TAPER DID NOT REDUCE } \\
\text { THE PEAK TORQUE. NO STRIP } \\
\text { CHART RECORD. VISUAL } \\
\text { INDICATION OF PEN MOVEMENT } \\
\text { ONLY. }\end{array}$ \\
\hline 3 & c & 300 & 1.500 & 7.500 & 18.460 & 2.25 & 1.57 & 30,575 & ${ }^{*}<1 \times 10^{-8}$ & $\begin{array}{l}\text { IMPROVED WELD FLASH EJECTION } \\
\text { OVER TEST } 1 .\end{array}$ \\
\hline 4 & D & 300 & 1.500 & 7.500 & 29.570 & 2.25 & .98 & 48.980 & ${ }^{\star}<1 \times 10^{-8}$ & $\begin{array}{l}\text { IMPROVED WELD FLASH EJECTION } \\
\text { OVER TEST } 3 . \text { VERY GOOD } \\
\text { LOOKIIG WELD. METALLOGRAPHY } \\
\text { SPECIMEN PREPARED. }\end{array}$ \\
\hline 5 & E & 330 & 1.560 & 8,000 & 31.540 & 2.25 & .98 & 48,980 & ${ }^{*}<1 \times 10^{-8}$ & $\begin{array}{l}\text { MARGINALLY BETTER FLASH } \\
\text { EJECTION THAN TEST } 4.32 \text { TON } \\
\text { REQUIRED TO PUSH OUT PLUG. }\end{array}$ \\
\hline 6 & E & 315 & 1.530 & 8.000 & 31.540 & 2.25 & .98 & 48.980 & ${ }^{\star}<1 \times 10^{-8}$ & $\begin{array}{l}\text { DUPLICATE OF TEST 5. WELD } \\
\text { SECTIONED. LOOKS VERY GOOD. }\end{array}$ \\
\hline 7 & $\mathrm{~F}$ & 310 & $>1,580$ & 8.000 & 51.520 & 2.00 & .60 & 80.000 & $\begin{array}{l}\text { GROSS } \\
\text { LEAK }\end{array}$ & $\begin{array}{l}\text { INSUFFICIENT SUPPORT OF JOINT } \\
\text { AREA. SHOULD HAVE REDUCED } \\
\text { WELIING FORCE. BROKE TORQUE } \\
\text { TRAFSDUCER. }\end{array}$ \\
\hline
\end{tabular}

FIGURE 5 
VACUUM TEST DATA

\begin{tabular}{|c|c|c|c|c|c|c|c|c|c|c|}
\hline $\begin{array}{c}\text { TEST } \\
\text { NUMBER }\end{array}$ & $\begin{array}{c}\text { JOINT } \\
\text { GEOMETRY }\end{array}$ & $\begin{array}{c}\text { WELDING } \\
\text { TORQUE } \\
\text { (ft-lbs) } \\
\end{array}$ & $\begin{array}{c}\text { PEAK } \\
\text { TORQUE } \\
\text { (ft-lbs) } \\
\end{array}$ & $\begin{array}{l}\text { WELOING } \\
\text { FORCE } \\
\text { (lbs) } \\
\end{array}$ & $\begin{array}{l}\text { JOINT } \\
\text { SURFACE } \\
\text { PRESSURE } \\
\text { (psi) } \\
\end{array}$ & $\begin{array}{l}\text { WELD } \\
\text { TIME } \\
(\mathrm{sec}) \\
\end{array}$ & $\begin{array}{l}\text { WELD } \\
\text { AREA } \\
\left(\text { in }^{2}\right) \\
\end{array}$ & $\begin{array}{r}\text { UNIT WELD } \\
\text { ENERGY } \\
\left(\mathrm{ft}-1 \mathrm{bs} / \mathrm{in}^{2}\right) \\
\end{array}$ & $\begin{array}{c}\text { LEAK RATE } \\
(\text { atm-cc/sec) }\end{array}$ & COMMENTS \\
\hline IVAC & E & - & - & 9.500 & 37.455 & - & .98 & 48.980 & $\begin{array}{l}\text { GROSS } \\
\text { LEAK }\end{array}$ & $\begin{array}{l}\text { TORQUE TRANSDUCER BROKEN. LOOKS LIKE } \\
\text { INSUFFICIENT MELD FORCE. NO BONDING } \\
\text { AT EDGES. RAM SPEED MAY BE TOO SLOW. }\end{array}$ \\
\hline 3VAC & D & 375 & 1.000 & 9.500 & 37.455 & 1.75 & .98 & 48,980 & $1 \times 10^{-9}$ & $\begin{array}{l}\text { 1/16 CHAMFER ON TOP EDGE OF LID HOLE } \\
\text { IS SUSPECTED CAUSE OF POOR FLASH } \\
\text { EJECTION ON TOP EDGE OF WELD. }\end{array}$ \\
\hline $4 V A C$ & 0 & 290 & 830 & 9.500 & 37.455 & 1.50 & .98 & 48.980 & $1 \times 10^{-10}$ & $\begin{array}{l}\text { PUSH-OUT TEST PERFORMED. ERROR IN } \\
\text { TEST SET-UP RESULTED IN A LOW PUSH-OUT } \\
\text { VALUE OF } 22 \text { TONS. WELD APPEARED TO BE } \\
\text { VERY GOOD. }\end{array}$ \\
\hline 5VAC & $D$ & 290 & 830 & 9.500 & 37,455 & 1.50 & .98 & 48.980 & ${ }^{*}<1 \times 10^{-9}$ & $\begin{array}{l}\text { VERY GOOD WELD. METALLOGRAPHY SAMPLES } \\
\text { PREPAEED. TENSILE TEST OF } \\
\text { APPROXIMATELY } 77 \text { KSI. }\end{array}$ \\
\hline
\end{tabular}

FIGURE 6 


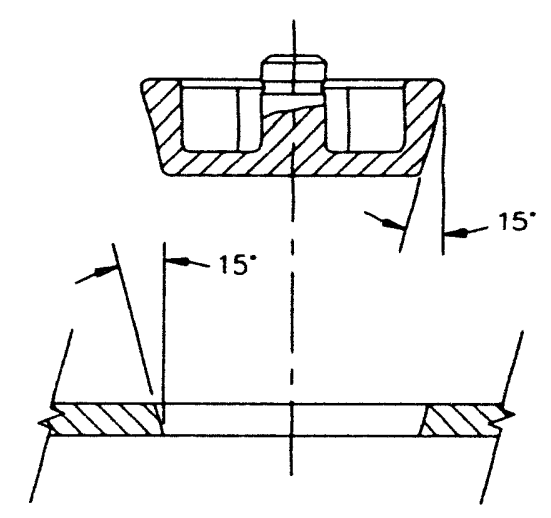

JOINT GEOMETRY "A"

$\stackrel{3}{3}$

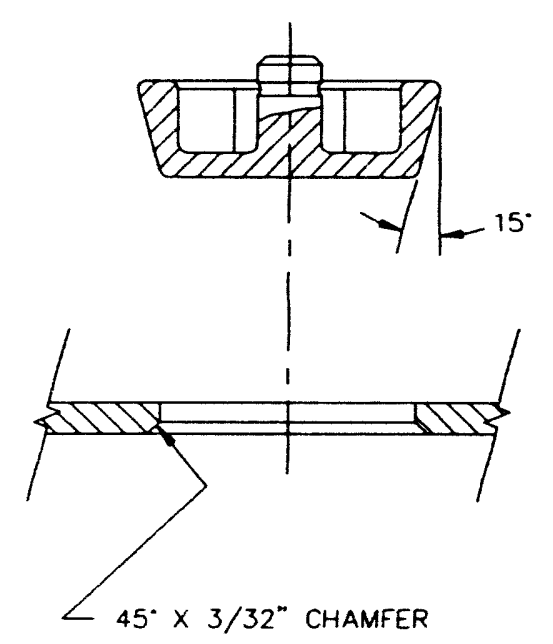

JOINT GEOMETRY "D"

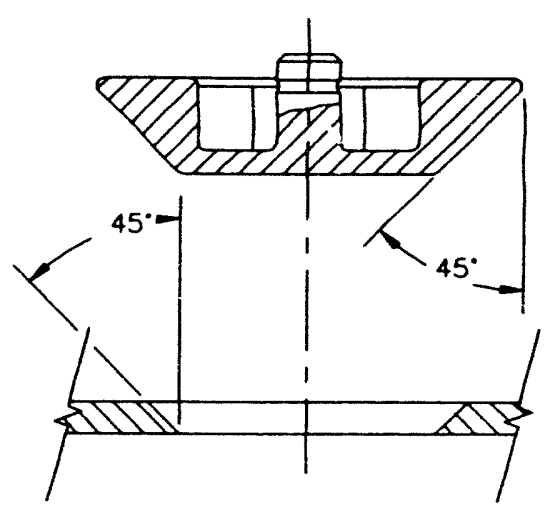

JOINT GEOMETRY "B"

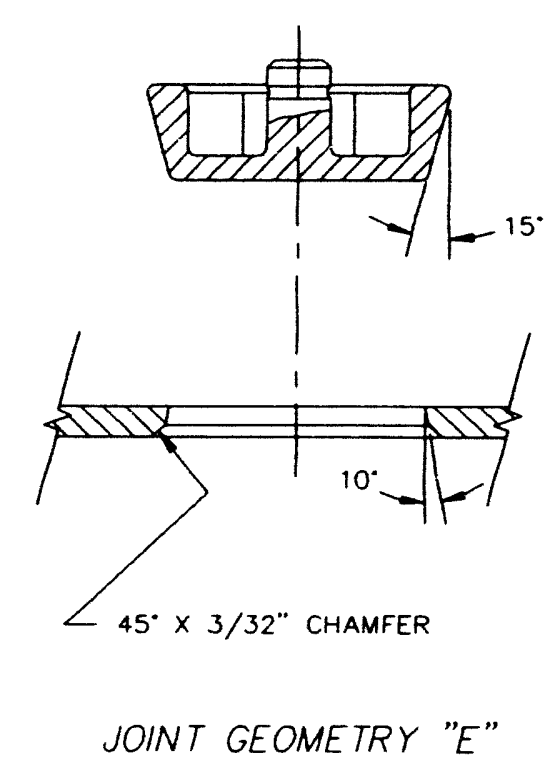

FIGURE 7

HECC FRICTION WELDING

JOINT GEOMETRIES

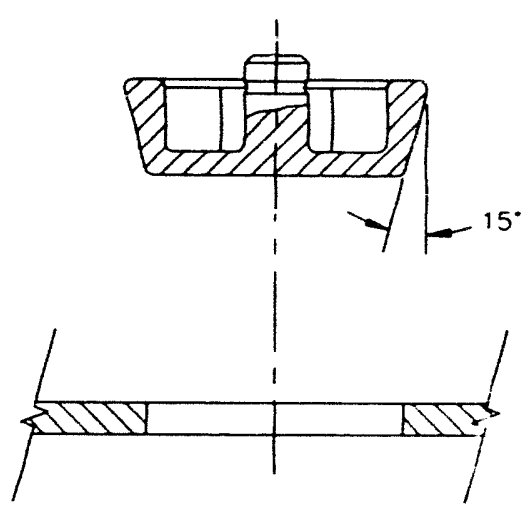

JOINT GEOME TRY "C"

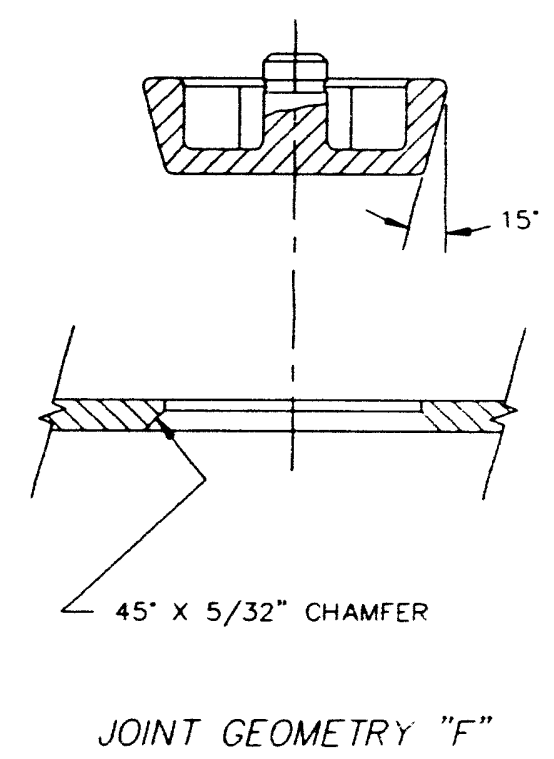

JOINT GEOMETRY "F" 
Attachment 8

June 23, 1993

TRR-02-93

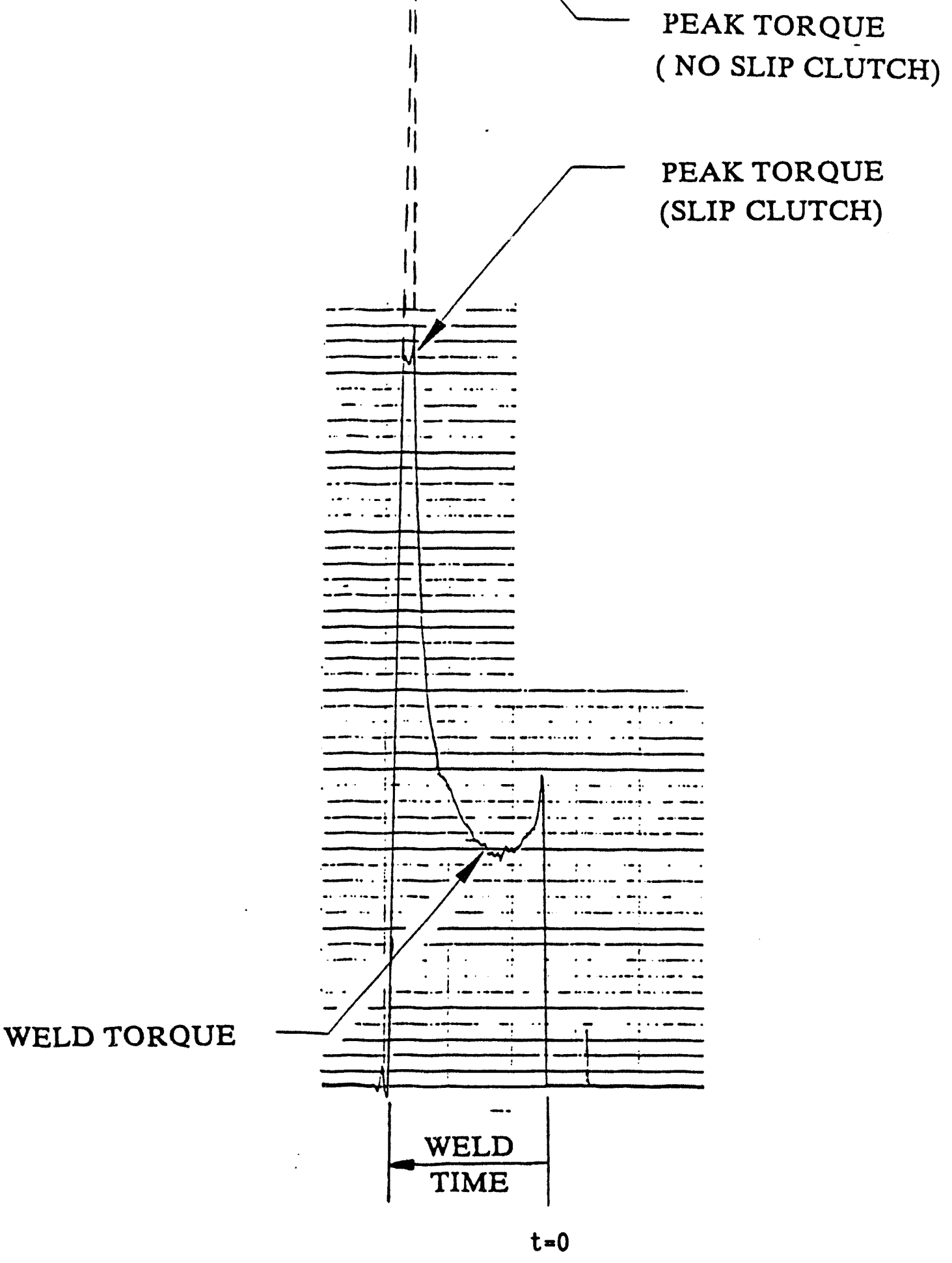

TYPICAL TORQUE CURVE

FIGURE 8

A.8 


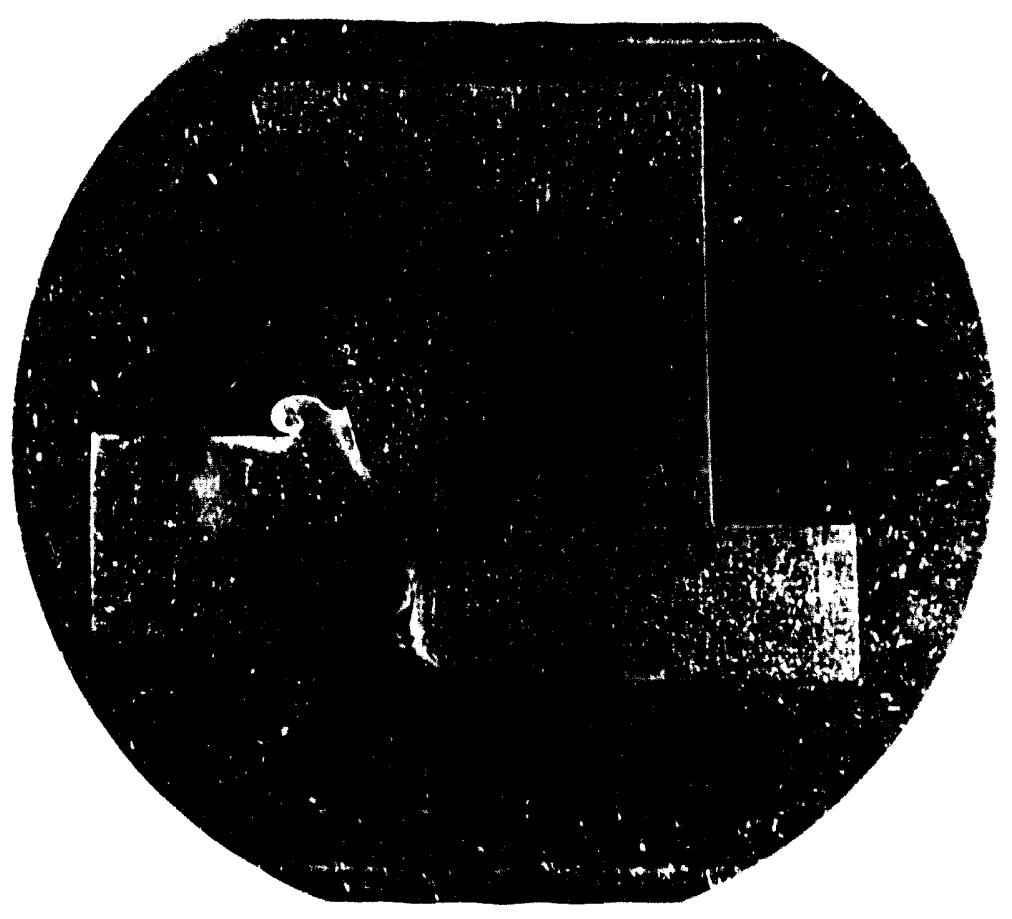

TEST SPECIMEN 5VAC 3X WELD JOINT

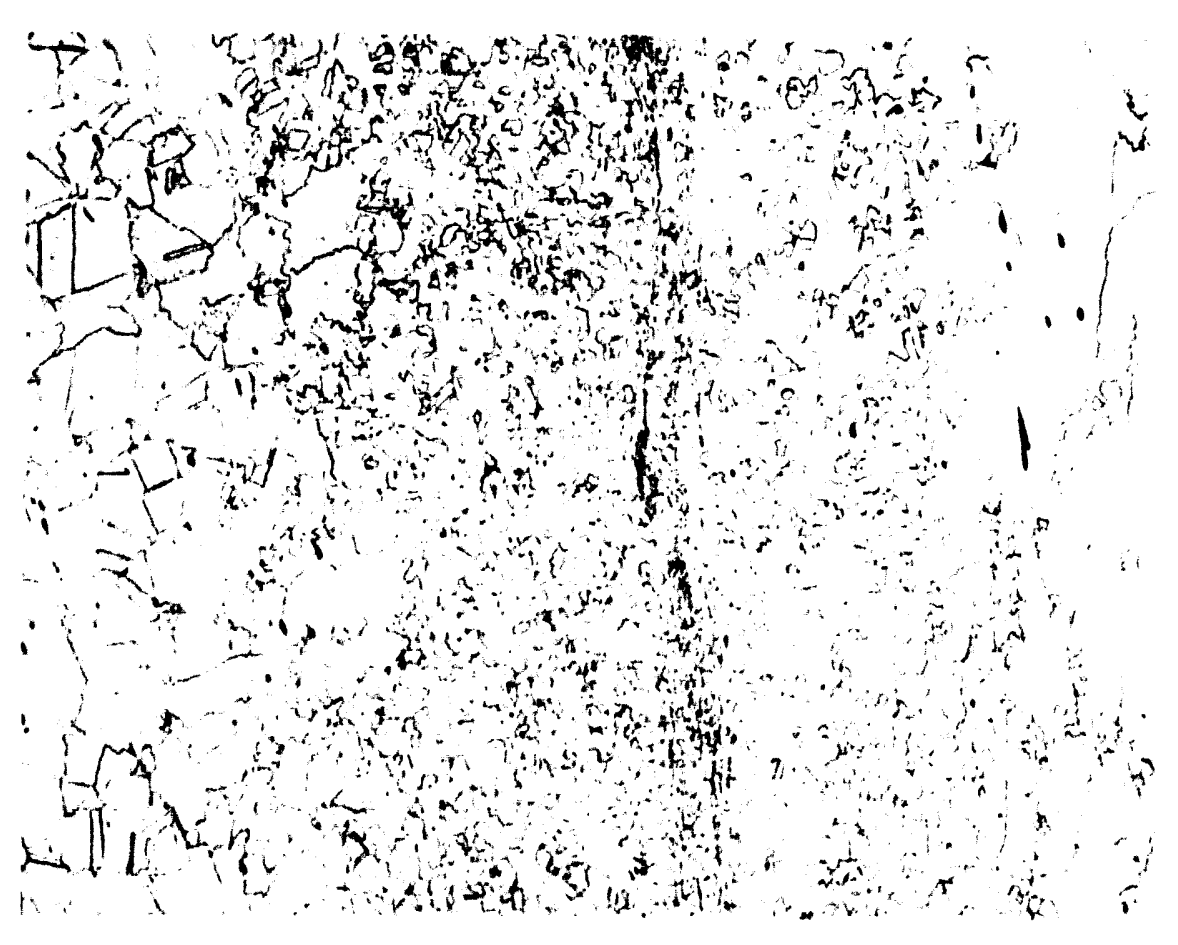

TEST SPECIMEN 5VAC

100X WELD JOINT

FIGURE 9 


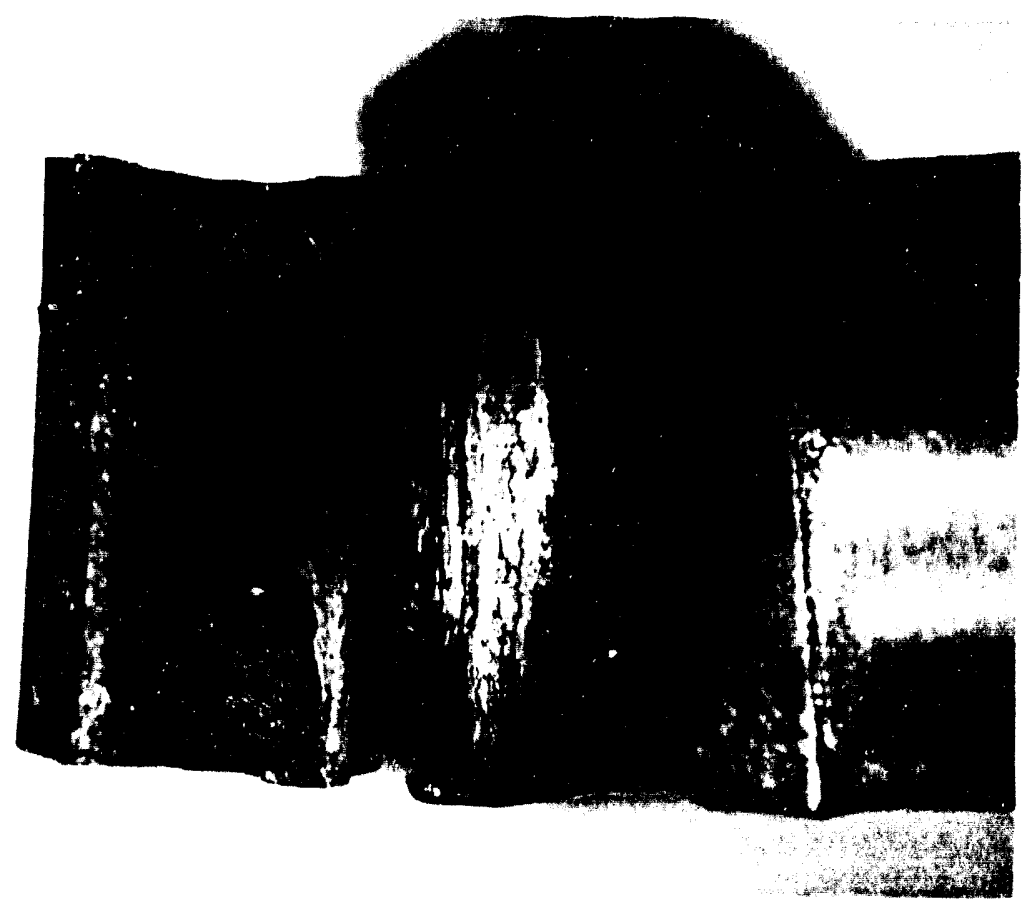

TEST SPECIMEN 5VAC

TENSILE TEST "A"

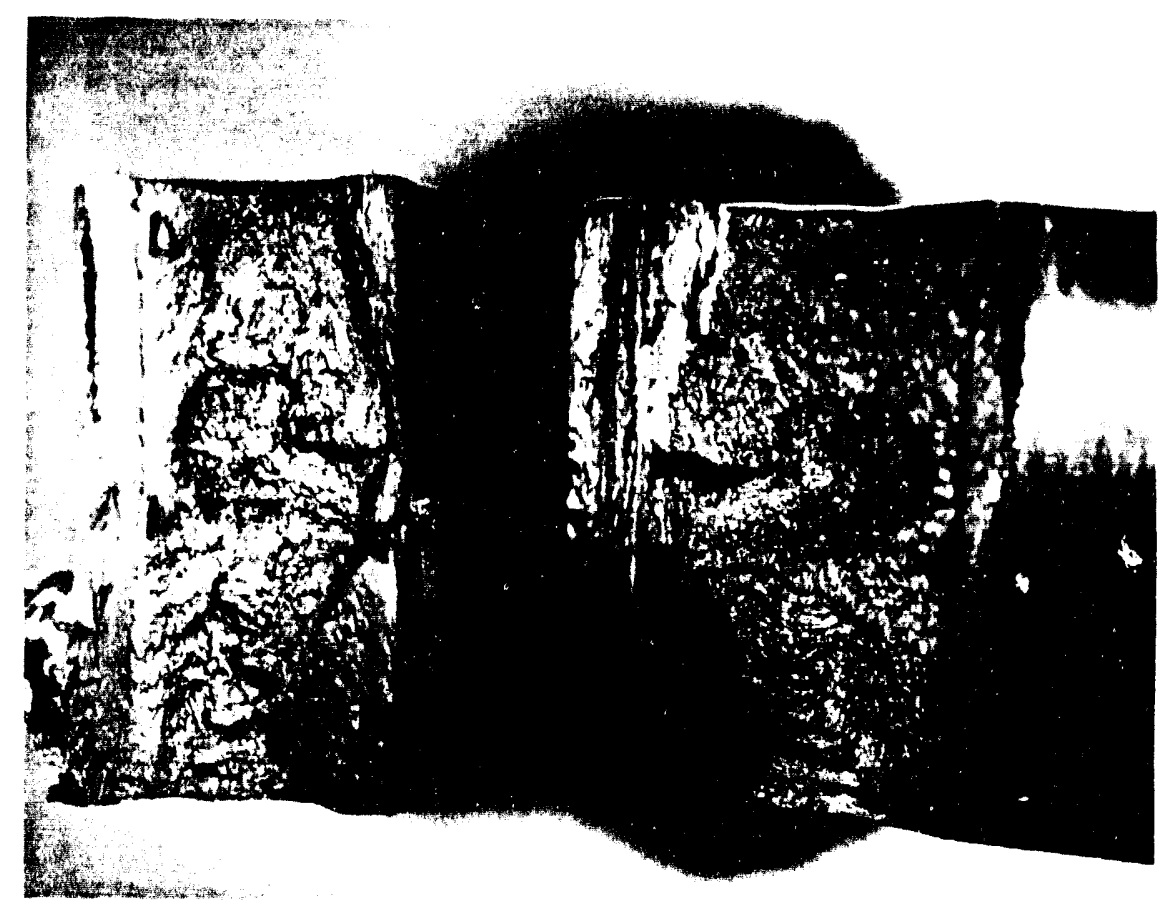

TEST SPECIMEN 5VAC

TENSILE TEST "B"

FIGURE 10 

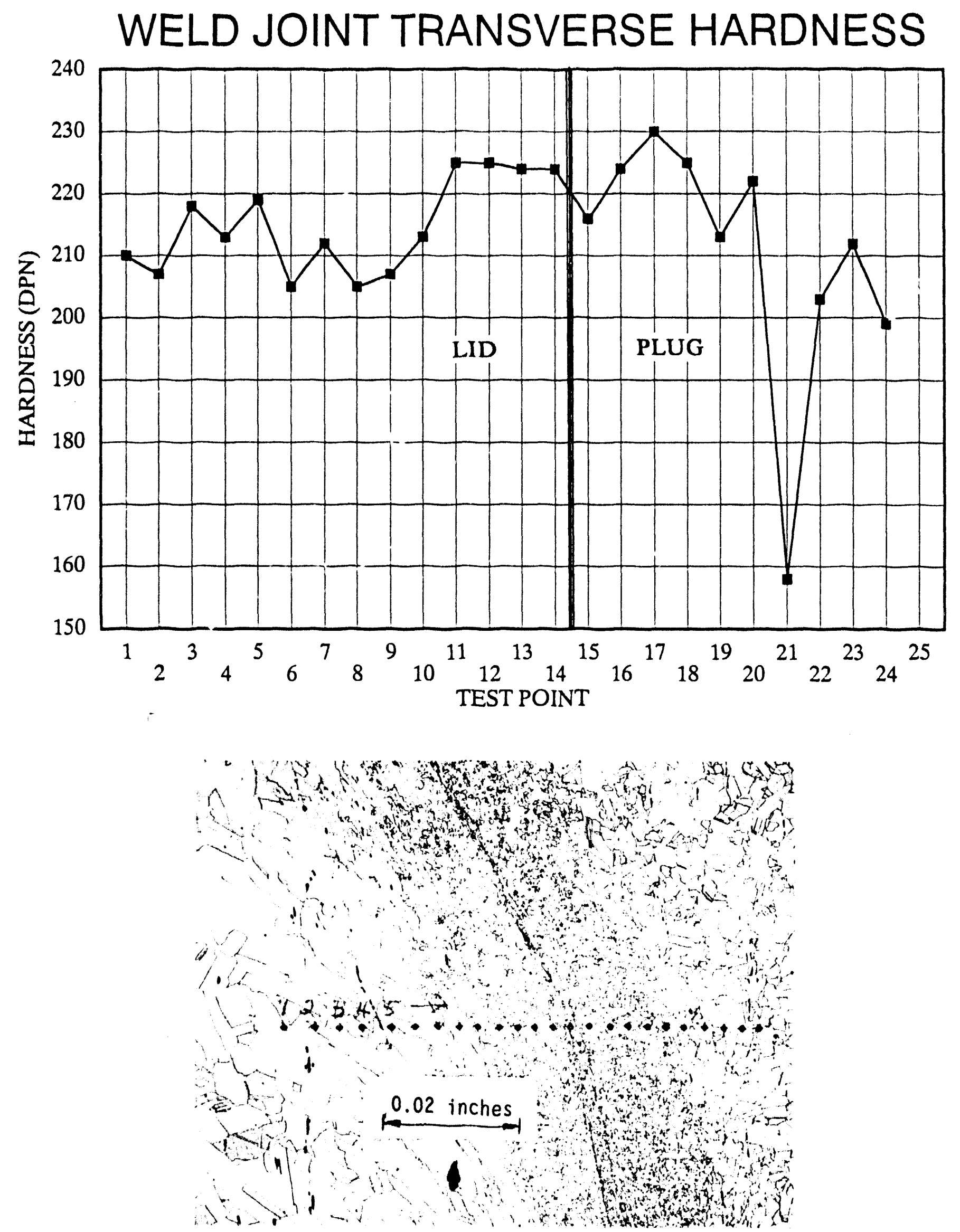

FIGURE 11

A-11 

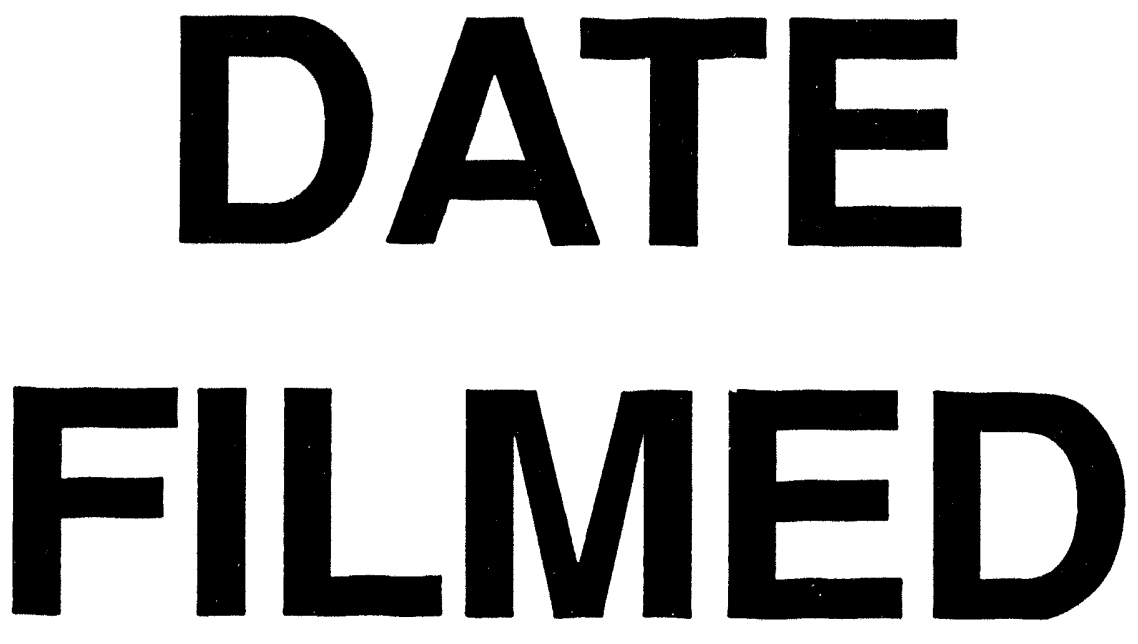

$9 / 12 / 94$
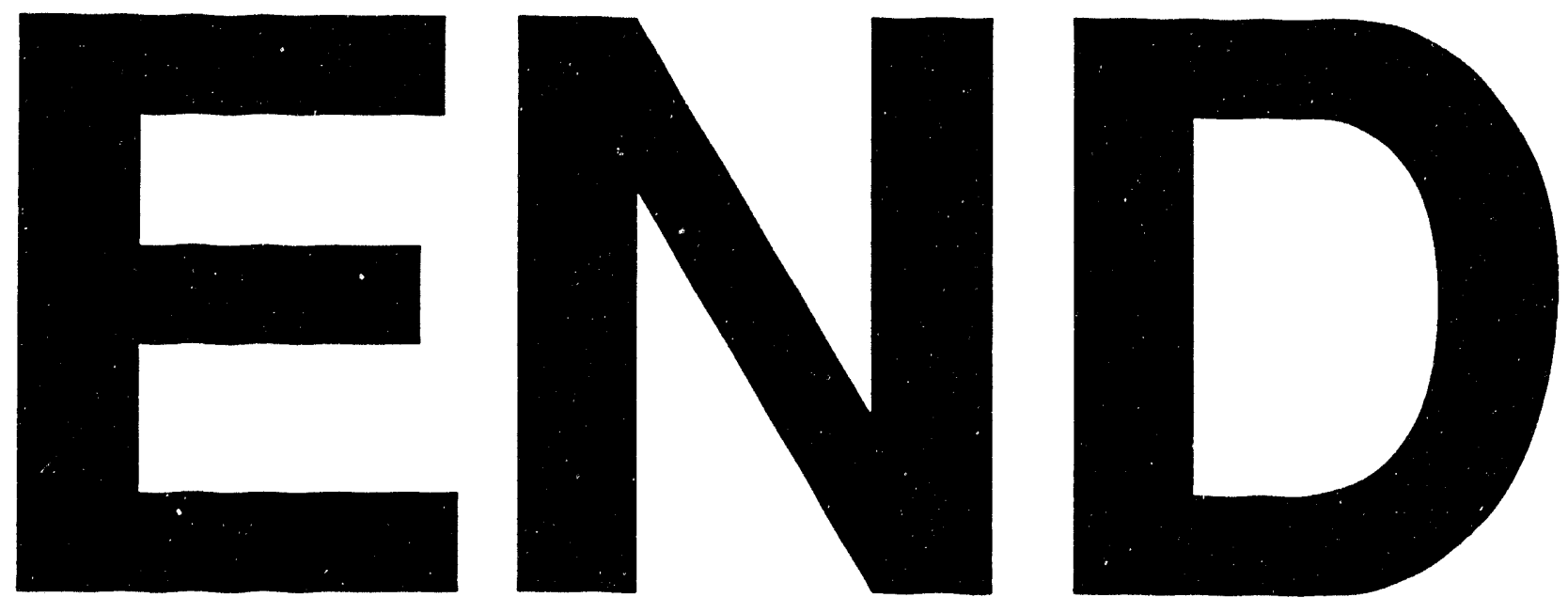
